\title{
STATUS, DISTRIBUTION AND HABITAT SPECIFICITY OF BENTHIC MACRO- INVERTEBRATES: A CASE STUDY IN FIVE TRIBUTARIES OF BUDDHIGANGA RIVER IN WESTERN NEPAL
}

\author{
Bipul Bhandari ${ }^{1}$, Ram Devi Tachamo Shah ${ }^{2 *}$, Subodh Sharma ${ }^{2}$

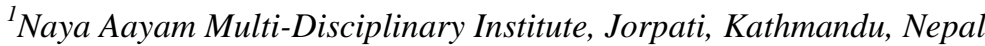 \\ ${ }^{2}$ Aquatic Ecology Centre, School of Science, Kathmandu University, Dhulikhel, Nepal \\ *Corresponding author: ramdevi.env@gmail.com
}

(Received: August 26, 2018; Revised: December 6, 2018; Accepted: December 8, 2018)

\begin{abstract}
Benthic macro-invertebrates are organisms that inhabit the bottom of substrates such as sediments, debris, logs, macrophytes and filamentous algae of streams, rivers and lakes for some span of their lifecycle. They are important part of food chain since they are source of food for different species of fishes and process organic matters. These organisms are considered vital tools to assess any environmental change caused by anthropogenic interference in the river ecosystems. In this study, we sampled macro-invertebrates from 5 different rivers across altitudinal ranges of $600-800 \mathrm{~m}$ and $1500-1700 \mathrm{~m}$ above sea level. We observed that the macro-invertebrate diversity varied substantially across altitudinal ranges. The diversity of macro-invertebrates was higher in lower altitudinal range, where 11 families were found, more than the higher altitudinal range. Some rare and dominant families were also identified in our study. We also examined the substrate specificity of macro-invertebrates. Results revealed that Ephemeroptera,Tricoptera, Coleoptera, Diptera and Odonata were found in all seven substrates namely bedrock, boulder, cobble, stone, pebble, gravel and sand. The richness and abundance of macro-invertebrates were documented in cobble, stone and pebble substrates. Similarly we also investigated the ecological river quality class of rivers using Ganga River System Biotic Score-Average Score per Taxon (GRS-BioS/ASPT) system which indicated good status. The outcomes of this study serve as a baseline data since no prior research has been done in these rivers.
\end{abstract}

Keywords: Abundance, Altitude range, Diversity, GRS-BIOS, Substrate

\section{INTRODUCTION}

The wetlands have highly diverse ecological attributes and provide important ecosystem services (Costanza et al. 1991). The ecological attributes of wetlands such as water storage capacity, biotic productivity, biogeochemical cycling and biodiversity have their importance for the functioning of wetland ecosystem (Stevenson \& Hauer 2002). Benthic macro-invertebrates are organisms that are small and inhabit the bottom of substrates such as sediments, debris, logs, macrophytes and filamentous algae of streams, rivers and lakes for some span of their lifecycle (Rosenberg \& Resh 1993). There are diverse group of benthic macro-invertebrates. They include insect larvae, annelids, oligochaetes, crustaceans, molluscs and gastropods. Insect larvae are the most abundant group of benthic macro-invertebrates in freshwater ecosystem (Rosenberg \& Resh 1993). The diversity and abundance of benthic macro-invertebrates alter with the changes in the quality of river ecosystem. There is a large number of macro-invertebrates species, the presence of which is used for different anthropogenic deteriorations: acidification, organic pollution, habitat modification and disturbances (Moog et al. 2008). The tolerances of macro-invertebrates to pollution vary greatly. Some macro-invertebrates are intolerant to pollution such as mayflies, stoneflies and caddisflies whereas worms, midges and molluscs are tolerant to pollution (Shah et al. 2008, Shah \& Shah 2013). Because of the changing pattern of diversity and abundance of macro-invertebrates they are widely used as pollution indicators. Biotic index for freshwater ecosystem was first developed in 1964 which is called Trent Biotic Index (TBI), originally developed for Tent River in England, (Metcalfe et al. 1989). Today, country specific biotic index is available in many countries for assessing ecological quality of surface water bodies. In Nepal, GRSBIOS-ASPT is outperformed biotic index (Shah \& Shah 2012).

Aquatic macro invertebrates play an important role in nutrient cycling and energy flow through lotic ecosystem since they process the organic matter and a primary source of food for fish. Benthic macro-invertebrates indicate any environmental changes in the river system such as organic pollution, hydro-morphological degradation, flow alteration etc. which is reflected by their abundance and diversity. Substrate is the primary physical environmental component affecting the assemblages of macroinvertebrates. They are the principal habitat for benthic macro-invertebrates and these organisms have different preference for substrate. Substrate is one of the abiotic factors that trap food, form river microhabitat and benthic shelter for macro-invertebrates (Mohmad et al. 2015, Wan Mohd Hafezul et al. 2016). Depending on the substrate 
type, different types of microhabitats are created that can change the turbidity, water flow and accumulation of debris at the surface of water (Annelise \& Gabriel 2002, Yule \& Yong 2004).

In order to conserve any species, its habitat i.e. niche should be recognized. From the habitat specificity analysis macro-invertebrates can be categorized into habitat specialist or generalist based on their presence on different substrates. Previous researches on substrate specificity have considered only few substrates, hence in this research the samplings were done from seven different substrates. Similarly the substrate can be categorized into highly preferable and least preferable. Habitat specialists are more vulnerable to different disturbance such as hydro-morphological degradation since they have few possible habitats and their conservation should be given a priority. In Karnali basin, only few studies have been done to access the fish diversity. The objectives of this research were to assess the community assemblages of benthic macroinvertebrates across altitudinal ranges, identify the habitat specificity of benthic macro-invertebrates and determine the ecological river quality status of rivers.

\section{MATERIALS AND METHODS}

\section{Study area}

Five tributaries of Buddhiganga river were chosen for the study. The five tributaries are Annai Khola (29 $27^{\circ}$

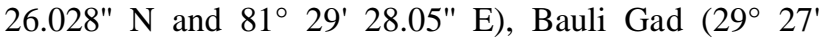
8.4852" $\mathrm{N}$ and $\left.81^{\circ} 29^{\prime} 22.6464^{\prime \prime} \mathrm{E}\right)$, Ekri Gad (29 $18^{\prime}$ 40.5504" $\mathrm{N}$ and $\left.81^{\circ} 15^{\prime} 51.444^{\prime \prime} \mathrm{E}\right)$, Jijadi Gad (29 $15^{\prime}$ 35.172" $\mathrm{N}$ and $\left.81^{\circ} 12^{\prime} 52.272^{\prime \prime} \mathrm{E}\right)$ and Chipke Khola (29 $16^{\prime} 14.0664^{\prime \prime} \mathrm{N}$ and $\left.81^{\circ} 11^{\prime} 23.3628^{\prime \prime} \mathrm{E}\right)$. The study area lies in two districts of western Nepal i.e. Bajura and Achham (Fig. 1).

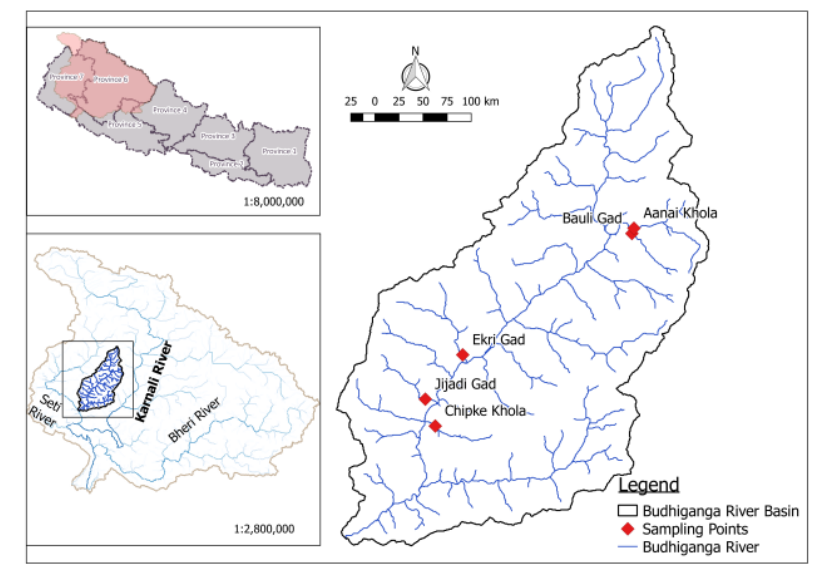

Fig. 1. Distribution of sampling sites in major tributaries of Buddhiganga River

Bajura lies in the north of Mahabharat range and its climate ranges from subtropical, temperate to cold temperate and alpine. On the other hand, Achham district has an elevational range of 540 to $3,820 \mathrm{~m}$ above sea level and its climate variation includes upper tropical, subtemperate to temperate.

\section{Data collection and analysis}

The sampling was done in five rivers out of which 3 rivers were from 600-800 $\mathrm{m}$ altitude and remaining two from $1500-1700 \mathrm{~m}$ altitude. The discharge along the cross section of each sampling site was measured using a velocity meter. The relative composition of different substrate within the $50-100 \mathrm{~m}$ river stretch was documented. Ten macro-invertebrates sampling was done from different substrate in each site. Macro-invertebrate sampling was done only from that substrate which comprised at least $10 \%$ of the area and number of samples increased with increasing percentage of habitat coverage (Shah et al. 2015). The macro-invertebrates sampling was done for base flow on February 2017 using a Surber sampler with an opening frame of $25 \mathrm{~cm} \times 25 \mathrm{~cm}$ and $500 \mu m$ mesh size net (Shah et al. 2013).

During the sampling, the intake of sampling net was placed against the flow and the substrate was disturbed within an area of $0.0625 \mathrm{~m}^{2}$. The substrate specific sample from the net was kept in 200-300 mL bottle and preserved in $85 \%$ ethanol for laboratory process. The sample when brought to laboratory was poured in a white tray with clear water and macro-invertebrates were sorted from the organic matter and kept separately in the vile. The family of macro-invertebrates was identified using a stereomicroscope and different available keys.

GPS points were taken from each sampling site. The correlation of benthic macro-invertebrates with substrate type and altitude was done using MS Excel. The GRSBIOS/ASPT was used for ecological river quality classification. The GRSBIOS includes 420 Taxa of family, genus and species level (Nesemann et al. 2007). This biotic scoring system was updated with new information regarding macro-invertebrates from the last decade. The faunal list in this scoring system was especially adapted for specific watershed called Ganges basin (Nesemann et al. 2007). The GRSBIOS was calculated by dividing the number of taxa score to the total number of scored taxa and the obtained numerical value was compared to its transformation table for determination of ecological river quality classes.

\section{RESULTS}

\section{Faunal composition}

Around 8376 benthic macro-invertebrates were identified from 5 rivers. The abundance of macro-invertebrates in higher altitude range was only 1514 which was considerably lower than 6862 macro-invertebrates individuals in lower altitude range (Fig. 2). 


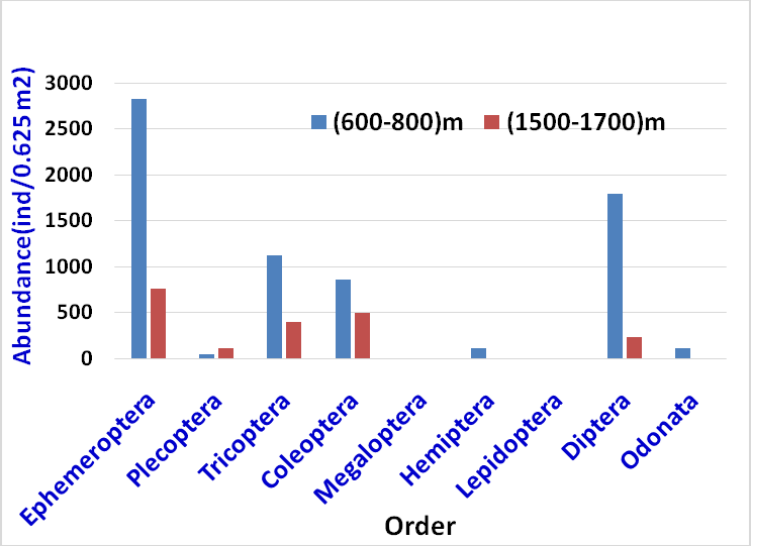

Fig. 2. Total individuals of macro-invertebrates with respective to Order

Overall 47 macro-invertebrates families were found from 9 orders in 5 rivers (Fig. 3). Some of the families of macro-invertebrates such as Leptophlebiidae, Ephemeridae, Ameletidae, Leuctridae, Apataniidae, Lepidostomatidae, Leptocheridae, Hydroptilidae, Goeridae, Psychomyiidae, Aphelocheiridae, Athericidae, Blephariceridae, Euphaeidae, Veliidae, Corydalidae, Hydrophilidae and Pyralidae were documented in one or two sites. The most diverse order of macro-invertebrates was Trichoptera with 15 families and the least diverse order were Megaloptera, and Lepidoptera with 1 family. Taxa richness was higher is (600-800) $\mathrm{m}$ altitude range with 40 macro-invertebrates families (Fig. 3) from 9 order while 29 families of macro-invertebrates were found from 7 orders in (1500-1700) $\mathrm{m}$ altitude range. Altogether 7 families of Ephemeroptera, 1 family of Plecoptera, 13 families of Trichoptera, 5 families of Coleoptera, 1 family of Megaloptera, 8 families of Diptera, 2 families of Heteroptera, 1 family of Lepidoptera and 2 families of Odonata were found in (600-800) $\mathrm{m}$ altitude range. Similarly, 5 families of Ephemeroptera, 3 families of Plecopteran, 10 families of Trichoptera, 1 family of Coleoptera, 1 family of Megalopteran, 8 families of Diptera and 1 family of Odonata were found in (15001700) $\mathrm{m}$ altitude range (Fig. 3).

\section{Habitat Specificity of macro-invertebrates}

Ephemeroptera were present in all substrates. Higher abundance of Ephemeroptera was recorded in stones, pebbles, sand, gravel and cobble (Fig. 4) while few families were present in substrates such as boulder, and bedrock (Fig. 5). Their abundance was highest in gravel with 1498 individuals. In case of Plecoptera, highest number was found in cobble. They were more abundant in cobble and stone followed by pebbles (Fig. 4). Plecoptera was not found in sand and bedrock (Fig. 5). Their family richness on other substrate is very low.

The richness of Trichoptera was more in cobble, stone, boulder and pebble (Fig. 5). They were abundant in cobble followed by boulder, stone and pebble. These orders of macro-invertebrates were found in all substrate. Coleoptera were present in all the substrate. However, their family richness was low in all the substrates. They were more abundant in pebble (Fig. 4).

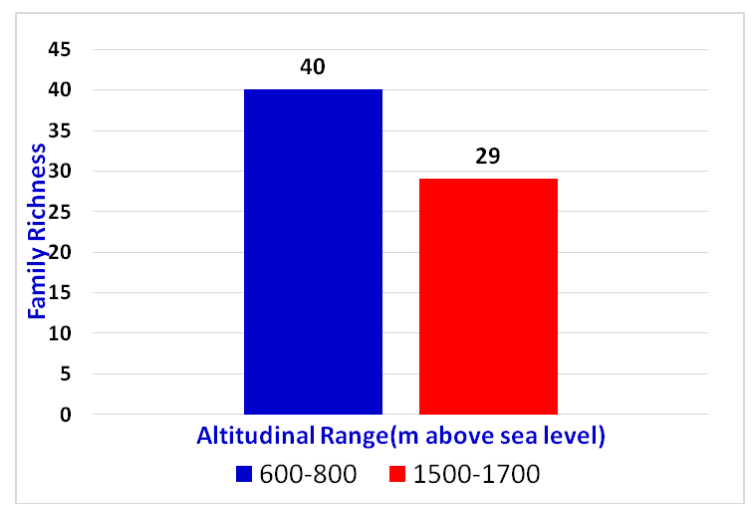

Fig. 3. Family richness of macro-invertebrates across altitudinal ranges

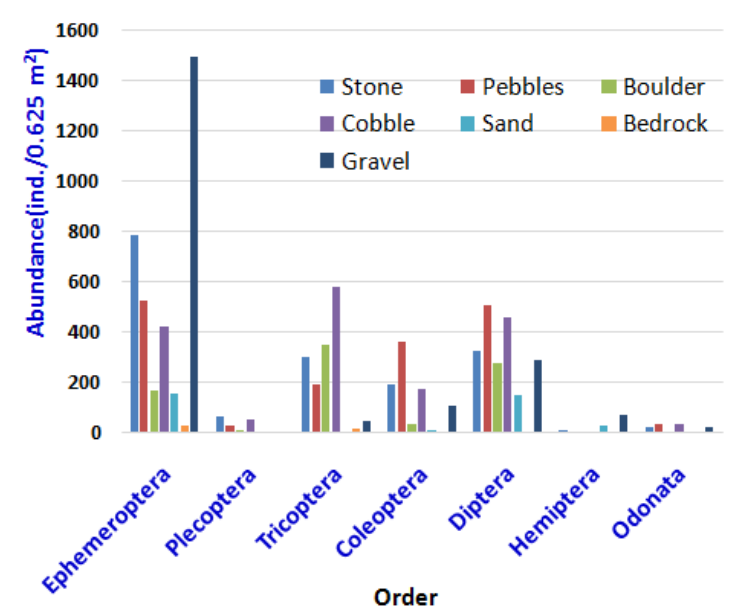

Fig. 4. Abundance of macro-invertebrates in different substrate types

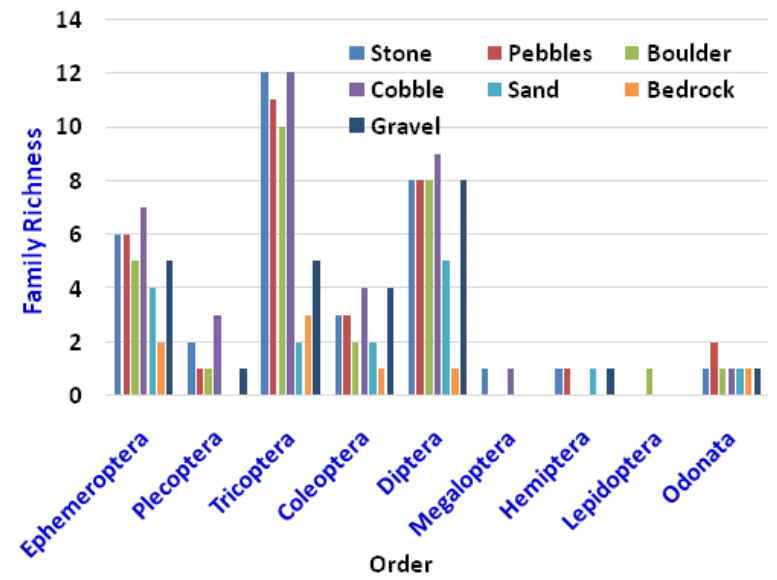

Fig. 5. Family richness of macro-invertebrates Order in different substrates 
Diptera taxa were found in all the substrates. They were equally diverse in stone, pebble, boulder, cobble and gravel while their diversity was low in sand and bedrock. Megaloptera and Lepidoptera were the order with least abundance and diversity (Fig. 5). Only one family of Megalopteran, i.e., Corydalidae was found in cobble and only Pyralidae was found from the order Lepidoptera on boulder. Only 2 families of odonatan were recorded in pebbles. They were found in all the substrate though their abundance and diversity was low (Figs 4 and 5). The Shannon diversity index was calculated for each substrate. The Shannon diversity values for cobble and bedrock were 2.68 and 1.22, respectively (Fig. 6).

\section{Shannon Diversity Index in Different Substrates}

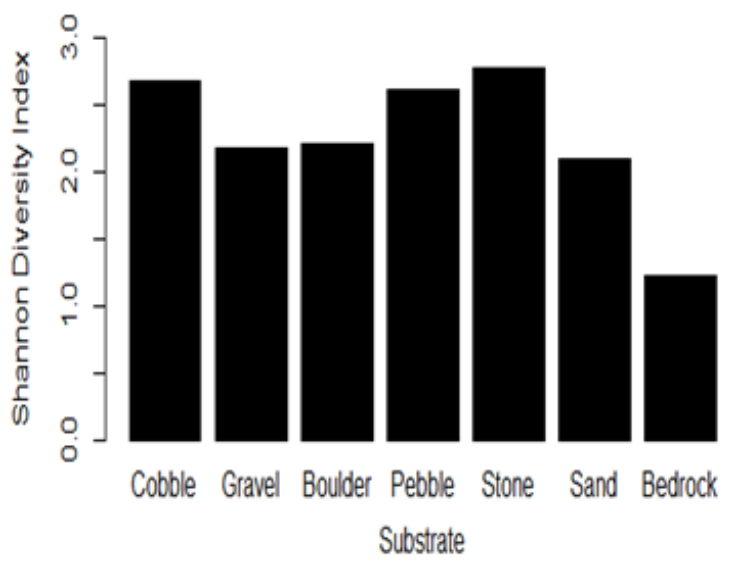

Fig. 6. Shannon Diversity Index in different substrates

\section{Ecological river quality assessment}

The ecological quality status of five rivers was assessed using GRS-BIOS/ASPT for midland. The GRSBIOS/ASPT showed the score varied from 6.75 to 7.0 suggesting that all the streams were in good river quality class (RQC) as shown in Table 1.

Table 1. Identification of water quality class using GRSBIOS

\begin{tabular}{|c|l|c|c|}
\hline $\begin{array}{c}\text { S. } \\
\text { No. }\end{array}$ & River & $\begin{array}{c}\text { GRSBIOS/ } \\
\text { ASPT }\end{array}$ & $\begin{array}{c}\text { River Quality } \\
\text { Class }\end{array}$ \\
\hline 1 & Jijadhi Gad & 6.75 & II \\
2 & Ekri Gad & 6.79 & II \\
3 & Bauli Gad & 7.00 & II \\
4 & AanaiKhola & 6.76 & II \\
5 & ChipkeKhola & 6.93 & II \\
\hline
\end{tabular}

\section{DISCUSSION}

There was a considerable difference in richness and abundance of macroinvertebrates in the two altitudinal ranges. Some of the dominant taxa of the study were Baetidae, Ephemerillidae, Caenidae, Heptaganidae, Elmidae, Limonidae and Chironomidae. Looking at the abundance, taxa such as Caenidae, Ephemerillidae,
Tricorythidae, Ueonidae, Elmidae, Hydropsychidae, Micronectidae, Psephenidae, Limonidae, Chironomidae, Ceratopogonidae and Gomphidae were common in (600$800) \mathrm{m}$ altitudinal range. The difference in family richness could be attributed to the fact that macro-invertebrates were sampled from only 4 sites of 2 rivers in 1500-1700 $\mathrm{m}$ altitudinal range. The other reason could be because the temperature and dissolved oxygen concentration in lower altitude rivers were suitable for majority of macroinvertebrates communities as well as availability of diverse microhabitats and refuge. Our observation was contradictory to numerous other studies on the altitudinal effect on benthic macro-invertebrates diversity. Pringle and Ramirez (1998) showed higher diversity in highland compared to lowland streams. Similarly positive correlation was found between altitude and richness in a catchment of Colorado (Tate \& Heiny 1995). Lang and Raymond (1993) found positive correlation between altitude and taxonomic richness in rivers of Switzerland. However, these studies were carried in low altitude of 100-300 m altitude where there were high anthropogenic deteriorations. But our study sites were relatively in natural states and carried out in limited altitudinal ranges of 600-800 $\mathrm{m}$ and $1500-1700 \mathrm{~m}$. The another reason for the difference in diversity and abundance across altitudinal ranges could be distribution of sampling sites in water abstracted rivers of higher altitude compared to the lower altitude. Water diversion in lotic ecosystem affects the natural flow regime by reducing the water volume and habitat availability (Benbow 1999). The loss of habitat area and alteration of food resource due to decreased flow alter the organism behavior and biotic interactions (Dewson et al. 2007). Some invertebrates are sensitive to the reduced flow.

This result showed that Ephemeroptera, Trichoptera, Coleoptera, Diptera and Odonata are habitat generalist since they are present in all the substrates, while Plecoptera, Megalopteran, Hemiptera and Lepidoptera indicated habitat specificity (Fig. 3). Similarly, macroinvertebrates from Hemiptera, Lepidoptera, Odonata and Megalopteran were less diverse and abundant. There was significant difference in family richness of macro-invertebrates among different substrates (one way analysis of variance; $\mathrm{F}=4.805, \mathrm{P}<0.001$ ). Highest diversity of macro-invertebrates was seen in cobble followed by stone. These substrates were stable and less susceptible to environmental disturbance. Reice (1985) also found that macro-invertebrates were most resilience to cobble because there were large quantities of interstitial space which provide diversified habitats for invertebrates to colonize and use as refuge (Duan et al. 2008). Bedrock has the lowest diversity of macroinvertebrates. From the results it can be seen that cobble, stone and pebbles were highly favorable habitat for macro-invertebrates in general because of the higher diversity and abundance in these substrates while gravel, 
sand and bedrock were less preferred habitat for most of the macro-invertebrates. Though Ephemeroptera abundance was highest in gravel with 1498 individuals, only some families of Ephemeroptera such as Caenidae and Ephemerilidae were most abundant in gravel indicating their preference. However, the abundance of other macro-invertebrates in this substrate was found relatively low.

The substrate such as cobble, stones and pebbles are more stable substrate and there is adequate supply of food resource and shelters and refuge (Dobson 1994, Bueno et al. 2003). These substrates are structurally complex as compared to other substrates (Barnes et al. 2013). Though bed rock and boulder are stable substrates, the richness and abundance of macro-invertebrates in these substrates were very minimal, which might be due to lack of food availability in these substrates. We collected macroinvertebrates only from the area of 0.0625 meter square which might be a reason for low diversity in bigger substrates. Similarly, difficulties in sampling of macroinvertebrates from boulders and bedrock also attributed for low diversity as they were embedded in the deeper sections of rivers. Considering the abundance of Ephemeroptera in gravel as the outlier of the study, gravel and sand can be considered substrates with lower abundance and richness of benthic macro-invertebrates. We observed that fine sediments reduced benthic macroinvertebrates diversity and abundance due to clogging, abrasion and burial reducing the food resources and organic compounds (Jones et al. 2012). These substrates are more susceptible to hydrodynamic alterations and inadequate supply of food resource (Bueno et al. 2003, Fidelis et al. 2008). Substrate such as cobbles, stones and pebbles capture more allochothonouse material underneath and also the algae and aquatic weeds can easily colonize in this substrate which might be a possible reason for greater diversity and abundance in the substrate. The result from study of Duan et al. (2008) showed that biodiversity is highest in pebbles, followed by stones and cobble and lowest in sand. This result was consistent with our study where cobbles and stones have the highest biodiversity i.e. the family richness were 37 and 34, respectively. The pebbles host 32 families. Similar to the study by Duan et al. (2008) sand was one of the least preferred substrate by benthic macro-invertebrates after Bedrock. Only 15 families were seen in sand and the total abundance was only 353 ind $/ 0.625 \mathrm{~m}^{2}$. Our results are also similar with that from (Parker, 1989) which showed that the abundance of benthic macro-invertebrates was greatest in gravel after the colonization time of 32 days.

This study compared the colonization of fine particulate organic matter and coarse particulate organic matter in gravel, pebble and cobble. The fine particulate organic matter (POM) was mostly captured by gravel while the coarse particulate organic matter was highest in cobble. Observations showed that benthic macro-invertebrates were more abundant in gravel indicating their preference for fine POM while the biomass was greatest in cobble.

In future, to identify the correlation between substrate and benthic macro-invertebrates, artificial substrate could be used. Artificial substrates provide advantages over natural substrates sampling because they can decrease the interreplicate differences in physical habitat and provide standardized sampling area which will increase precision in sampling and show clear distinction in biota among sites (Paller 1996). Regardless of the type of substrate, there are other factors in substrate such as the surface texture which determines the benthic macro-invertebrates behavior i.e. community structure which has not be controlled in this study. Research by Schmude et al. (1998) showed that more macro-invertebrates were found in substrate with physical complexity. Clifford et al. (1992) stated that the macro-invertebrates preference for rough surface is due to the availability of more secure attachment sites which help them to avoid fast currents. In addition, surface complexity also facilitates differences in food resources, i.e., algae colonize more quickly on rough surface as compared to smooth surface (Clifford et al. 1992). Macroinvertebrates respond differently to the surface complexity. Chironomids and Hydropsychidae tend to colonize more in rough substrate while Simulidae preferred smoother surface (Molokwu et al. 2014) Research by Molokwu et al. (2014) showed that temporal variation is another aspect that affects the colonization of macro-invertebrates. Seasonality is another aspect which controls the colonization and distribution of benthic macro-invertebrates in different substrates which was not considered in this study (Jahnig \& Lorenz 2008).

\section{CONCLUSION}

From the observation we concluded that altitude is one of the major factors that affect the diversity and abundance of macro-invertebrates. Results showed that more diverse and abundant macro-invertebrates were found in the altitude range of 600-800 $\mathrm{m}$ compared to altitudinal range of $1500-1700 \mathrm{~m}$. In future research the taxonomic richness along altitude could be done in steeper gradient with more altitudinal ranges. It has shown the significance of substrate in the distribution and composition of benthic macro-invertebrates in the subtropical and temperate rivers. Higher Shannon diversity values were seen in cobbles, stones and pebbles substrates. Therefore, stone and gravel mining in streams and rivers could have serious implication in the preservation of aquatic biodiversity of Nepal. Similarly, highly preferred substrates of different orders have been recognized in this study which provided better understandings regarding conservation practices. In future research, artificial substrates could be used and the surface texture of 
Status, distribution and habitat specificity of benthic micro-invertebrates: a case study ...

substrates could be controlled. Nevertheless, this research can be used as baseline study of macro-invertebrates assemblage in tributaries of Buddhiganga River.

\section{ACKNOWLEDGEMENT}

The field work of this study was supported by the International Water Management Institute (IWMI), Nepal through Digo Jal Vikash project.

\section{REFERENCES}

Annelise, G. and Gabriel, M.J.M. 2002. Aquatic invertebrates of South African rivers: Field guide. Institute for Water Quality Studies, Department of Water Affairs and Forestry, Pretoria, pp. 78.

Barnes, J.R.,Vaughan, I,P. and Ormerod, S.J. 2013. Reappraising the effect of habitat structure on river macro-invertebrates. Freshwater Biology 58: 21542167.

Benbow, M.E. 1999. Natural spate disturbance and decreased discharge in a Hawaiian stream: fluctuating stability in a torrential environment. M. Sc. Thesis, University of Dayton, Dayton.

Bueno, A.A.P., Bond-Buckup, G. and Ferreira, B.D.P. 2003. Estrutura da comunidade de invertebrados bentônicos em dois cursos d'água do Rio Grande do Sul. Revista Brasileira de Zoologia 20: 115-125 (abstract in English).

Clifford, H.F., Casey, R.J. and Saffran, K.A. 1992. Shortterm colonization of rough and smooth tiles by benthic macroinvertebrates and algae (chlorophyll-a) in 2 streams. Journal of North American Benthological Society 11: 304-315.

Costanza, R.D., Arge, R., Degroot, S., Farber, M., Grasso, B., Hannon, K., Limburg, S., Naeem, R., Neill, J., Paruelo, R., Raskin, P. and Van Den Belt, M. 1991. The value of the world's ecosystem services and natural capital. Nature 387: 253-260.

Dewson, Z.S., James, A.B.W. and Death, R.G. 2007. Invertebrate responses to short-term water abstraction in small New Zealand streams Freshwater Biology 52: 357-369.

Dobson, M. 1994. Microhabitat as a determinant of diversity: stream invertebrates Colonizing leaf packs. Freshwater Biology 32: 565-572.

Duan, X., Wang, Z. and Tian, S. 2008. Effect of streambed substrate on macro-invertebrate biodiversity. Frontiers of Environmental Science and Engineering 2(1): 122-128.

Fidelis, L., Nessimian, J.L. and Hamada, N. 2008. Distribuiçãoespacial de insetos aquáticosemigarapés de pequenaordemna Amazônia Central. Acta Amazonica 38: 127-134.

Jahnig, S.C and Lorenz, A.W. 2008. Substrate-specific macro-invertebrate diversity patterns following stream restoration. Aquatic Science 70: 292-303.

Jones, J.I., Murphy, J.F., Collins, A.L., Sear, D.A., Naden, P.S. and Armitage, P.D. 2012. The impact of fine sediment on macro-invertebrates. River Research and Applications 28: 1055-1071.

Lang, C. and Raymond, O. 1993. Empirical relation between diversity of invertebrate's communities and Altitudinal Rivers: application to bio-monitoring. Aquatic Science 55(3): 188-196.

Metcalfe, J. L. 1989. Biological water quality assessment of running waters based on macroinvertebrate communities: History and present status in Europe. Environmental Pollution 60(1): 101-139.

Mohmad, A.H., Andrew Wong, B.H., Faizul Hafizi, M., Ernie Humaira, A.F. and SitiJuliyana, K. 2015. Diversity, composition and distribution of aquatic insects in Liwagu Water Catchment, Tambunan, Sabah. Journal of Tropical Biology and Conservation 12: 13-24.

Molokwu, N.D., Pedro, G., Bradshaw, T., Blake, A., Henessey, C. and Merten, E. 2014. Effects of substrate on the benthic macro-invertebrate community: an experimental approach. Ecological Engineering73: 109-114.

Moog, O., Hering, D., Sharma, S., Ilse, S., and Korte, T. 2008. Contribution to the knowledge of aquatic macro-invertebrates from Hindu Kush-Himalaya. Proceedings of scientific conference: Rivers in Hindu-Kush Himalayan Region Ecological and Environmental Assessment. Vienna, Austria, pp. 1202.

Nesemann, H., Sharma, S., Sharma, G., Khanal, S.N., Pradhan, B.,Shah, D.N and Tachamo, R.D. 2007. Aquatic Invertebrates of the Ganga River System. Hasko Nesemann, Kathmandu, Nepal, pp. 263.

Paller, M.H. 1996. Effectiveness of multiplate invertebrate samplers, periphytometers and electrofishing for biomonitoring in streams. Water Research 30: 2095-2101.

Parker, M.S. 1989. Effect of substrate composition on detritus accumulation and macroinvertebrate distribution in a southern Nevada desert stream. The Southwestern Naturalist 34(2): 181-187.

Pringle, C.M. and Ramirez, A. 1998. Use of both benthic and drift sampling techniques to assess tropical stream invertebrate communities along altitudinal 
gradient, Costa Rica. Freshwater Biology 39: 359 373.

Reice, S.R. 1985. Experimental disturbance and the maintenance of species diversity in a stream community. Oecologia 67(1): 90-97.

Rosenberg, D.M. and Resh, V.H. 1993. Introduction to freshwater biomonitoring and benthic macroinvertebrates. Springer, New York, USA, pp. 488.

Schmude, K.L., Jennings, M.J., Otis, K.J. and Piette, R.R. 1998. Effects of habitat complexity on macroinvertebrate colonization of artificial substrates in north temperate lakes. Journal of North American Benthological Society 17(1): 73-80.

Shah, D.N., Tachamo, R.D., Sharma, S. and Moog, O. 2008. Cause and implications of urban river pollution, mitigative measures and benthic macroinvertebrates as river monitoring tool. Feyen, J., Shannon, K. and Neville, M. (ed). In Proceedings of International Conference on Water and Urban Development Paradigms: Towards an Integration of Engineering, Design and Management Approaches, pp. 419-424.

Shah, R.D.T and Shah, D.N. 2012. Performance of different biotic indices assessing the ecological status of rivers in the central Himalaya. Journal of Ecological Indicator 23: 447-452.

Shah, R.D.T. and Shah, D.N. 2013. Evaluation of benthic macroinvertebrate assemblage for disturbance zonation in urban rivers using multivariate analysis: Implications for river management. Journal of Earth System Science 122(4): 1125-1139.

Shah, R.D.T., Sharma, S., Haase, P., Jähnig, S. and Pauls, S. 2015. The climate sensitive zone along an altitudinal gradient in central Himalayan rivers: a useful Concept to monitor climate change impacts in mountain regions. Climatic Change 132(2): 265-278.

Stevenson, R.J. and Hauer, F.R. 2002. Integrating hydrogeomorphic and index of biotic integrity approaches for environmental assessment of wetalnds. Journal of the American Benthological Society 21: 502-513.

Tate, C.M. and Heiny, J.S. 1995. The ordination of the benthic invertebrate's communities in the South Platte River basin in relation to environmental factors. Freshwater Biology 33: 439-454.

Wan Mohd Hafezul, W.A.G., Che Salmah, M.R., Suhaila, A.H., Salman, A.A.S., Abu Hassan, A. and Ahmad Najmi, N.H. 2016.Variation in environmental conditions influences diversity and abundance of Ephemeroptera in forest streams of Northern Peninsular Malaysia. Journal of Tropical Ecology 57(3): 489-501.

Yule, C.M. and Yong, H. S. 2004. Freshwater invertebrates of the Malaysian region. Academy Of Science, Kuala Lumpur, Malaysia. Pp. 861. 